\title{
Insulin sensitivity and glucose tolerance improve in patients with acromegaly converted from depot octreotide to pegvisomant
}

\author{
W M Drake, S V Rowles, M E Roberts, F K Fode, G M Besser, J P Monson and P J Trainer \\ Departments of Endocrinology, St Bartholomew's Hospital, London, UK and Christie Hospital, Manchester, UK \\ (Correspondence should be addressed to W M Drake, Department of Endocrinology, St Bartholomew's Hospital, West Smithfield, London EC1A 7BE, UK; \\ Email:w.m.drake@qmul.ac.uk)
}

\begin{abstract}
Aim and method: Insulin resistance leading, in some cases, to glucose intolerance is an important contributory factor to the cardiovascular morbidity and mortality associated with acromegaly. The aim of this study was to document changes in insulin sensitivity (IS) in a group of seven patients with acromegaly (three male, four female, mean \pm S.D. age $59 \pm 13$ years) treated initially with a stable dose of depot octreotide (OT; median dose $30 \mathrm{mg}$ four times weekly, range $10-30 \mathrm{mg}$ ) for a median of 18 months (range 16-19 months) and who were then transferred to treatment with pegvisomant (median dose $15 \mathrm{mg}$ daily, range $10-20 \mathrm{mg}$ ) for a median of 8 months (range 7-9 months). IS was assessed by homeostatic model assessment (HOMA) using fasting glucose and insulin concentrations and by a short insulin tolerance test (sITT). Body composition was assessed by dual energy X-ray absorptiometry.

Results: Mean \pm S.D. serum IGF-I concentrations during therapy with OT and with pegvisomant were not statistically different $(283 \pm 119 \mathrm{ng} / \mathrm{ml}$ on OT vs $191 \pm 39 \mathrm{ng} / \mathrm{ml}$ on pegvisomant $(P=0.4))$. However, mean \pm S.D. fasting plasma glucose fell from $6.2 \pm 1.0 \mathrm{mmol} / \mathrm{l}$ on OT to $5.2 \pm 0.6 \mathrm{mmol} / \mathrm{l}$ on pegvisomant $(P=0.017)$ and was lower on pegvisomant in all seven patients. In four patients, fasting plasma glucose fell from values diagnostic of diabetes mellitus or impaired fasting glucose on OT to within the normal range on pegvisomant. Mean \pm S.D. peripheral IS (by sITT) increased from $139 \pm 39 \mu \mathrm{mol} / \mathrm{l}$ per $\min$ on OT to $169 \pm 59 \mu \mathrm{mol} / \mathrm{l}$ per $\min$ on pegvisomant $(P=0.037)$. Mean \pm S.D. IS (by HOMA $\%$ S) was unchanged over the course of the study $(149.1 \pm 43.7 \%$ on OT vs $139.9 \pm 76.6 \%$ on pegvisomant, $P=0.28)$. Mean \pm S.D. pancreatic $\beta$-cell secretory function (HOMA \%B) improved significantly on pegvisomant compared with OT $(49.4 \pm 19.2 \%$ vs $82.4 \pm 43.5 \%, P=0.01)$. No statistically significant change in total fat $(P=0.3), \%$ fat $(P=0.28)$ or circulating non-esterified fatty acids $(P=0.35)$ was observed.

Conclusions: IS and glucose tolerance improved in patients converted from OT therapy to pegvisomant, without a change in body composition and even when serum IGF-I concentrations remained equally well controlled. This may be an important factor in the choice of medical therapy for patients with acromegaly.
\end{abstract}

European Journal of Endocrinology 149 521-527

\section{Introduction}

It is well established that aggressive control of the growth hormone $(\mathrm{GH}) /$ insulin-like growth factor-I (IGF-I) axis restores the excess mortality rate associated with acromegaly to that of the general population $(1,2)$. However, transsphenoidal surgical adenomectomy establishes 'safe' GH levels in less than $50 \%$ of patients with a macroadenoma (3) and external beam pituitary irradiation, although an effective adjunctive treatment, works slowly $(4,5)$. Hence, many patients who are not cured by surgery or who are awaiting the effects of pituitary irradiation, require medical therapy to control the GH/IGF-I axis. Current options for medical therapy include dopamine agonists (usually cabergoline (6)) and somatostatin analogues, either in short-acting form (octreotide acetate (7)) or as intramuscular depot preparations (octreotide (8) or lanreotide (9)). The advent of the GH receptor (GHR) antagonist pegvisomant, which is able to normalise serum IGF-I concentrations in $97 \%$ of patients with active acromegaly (10-12), means that endocrine physicians will soon have several options for medical therapy available for use either alone or in combination.

The increased cardiovascular morbidity and mortality associated with acromegaly is, at least in part, consequent upon the increased insulin resistance (IR) that frequently accompanies $\mathrm{GH}$ hypersecretion. Somatostatin analogues achieve 'safe' GH and IGF-I concentrations in approximately $60 \%$ of patients, but 
their inhibitory effect on pancreatic insulin secretion dictates that their overall effect on glucose tolerance is complex and unpredictable $(13,14)$. It is therefore possible that differences in the effect of somatostatin analogues and pegvisomant on insulin sensitivity (IS) and glucose tolerance may influence the choice of medical therapy for an individual patient. The aim of this study was to compare IS, using two complementary methodologies, in a group of seven patients with active acromegaly converted from stable therapy with a long-acting somatostatin analogue to treatment with pegvisomant.

\section{Patients and methods}

\section{Patients}

Details of the seven patients (three male, four female, mean \pm S.D. age $59 \pm 13$ years) studied are given in Table 1. All had active acromegaly and were receiving appropriate replacement therapy for the pituitary hormone deficits as shown, doses of which did not change during the course of the study (Table 1).

\section{Study protocol}

The patients were participating in a multi-centre, openlabel study of the efficacy of pegvisomant in the treatment of acromegaly. All were treated with a stable dose of depot octreotide (OT; median duration of treatment 18 months, range 16-19 months (Navartis Pharma AG)) and all were receiving the maximum effective dose (median $30 \mathrm{mg}$ four times weekly, range $10-30 \mathrm{mg}$ ), judged by the mean of five serum GH concentrations taken through the day and serum IGFI measurements. Following informed, ethical boardapproved consent, the next scheduled OT injection was withheld and treatment with pegvisomant (Pharmacia Corp.) commenced, initially at a dose of $10 \mathrm{mg}$ once daily by subcutaneous injection. The dose of pegvisomant was increased, if necessary, every 8 weeks, up to a maximum of $25 \mathrm{mg}$ daily, in order to maintain the serum IGF-I concentration within the age-adjusted normal range.

IS was measured at baseline (on OT, within $48 \mathrm{~h}$ of the scheduled, withheld dose) and again after a median of 8 months (range 7-9 months) therapy with pegvisomant and was assessed by two methods: homeostatic model assessment (HOMA) and a short insulin tolerance test (sITT). In the latter test, with the patient in the fasting state, $0.1 \mathrm{IU} / \mathrm{kg}$ body weight of soluble insulin is injected intravenously and samples drawn for plasma glucose at $0,3,4,6,7,8,9,10,11$, $12,13,14$ and $15 \mathrm{~min}$. The rate of fall of plasma glucose (calculated using Excel, Microsoft, Seattle, WA, USA) provides a reproducible measure of peripheral IS and has been validated against the 'gold standard' hyperinsulinaemic euglycaemic clamp (15). The HOMA is a computer solved model for predicting IS $(\% \mathrm{~S})$ and $\beta$-cell deficiency $(\% \mathrm{~B})(16)$ and has been shown to be useful for predicting IS in acromegaly (17).

\section{Measurements and assays}

Plasma glucose was measured by the glucose oxidase method. Plasma insulin concentrations were determined by chemiluminescent immunometric assay using the Immulite 2000 analyser (Diagnostic Product Corporation, Llanberris, Gwynedd, UK). Serum IGF-I was measured by a competitive binding radioimmunoassay (Nichols Institute Diagnostics, San Juan Capistrano, CA, USA). Total non-esterified fatty acids (NEFAs) were quantitated by colorimetric assay, using a commercial kit (Alpha Laboratories Ltd, Eastleigh, Hants, UK) and the Cobas MIRA analyser (Roche Diagnostics Corporation, Indianapolis, IN, USA). Body composition (total fat and \% fat) was assessed by dual energy X-ray absorptiometry (DXA), using either a Hologic QDR-1000 (Hologic, Waltham, MA, USA) or a Lunar DPX (Lunar, Madison, WI, USA) densitometer. Baseline and follow-up scans were performed on the same instrument for each patient and each instrument underwent daily standard calibration using the appropriate manufacturer's phantom.

\section{Statistical analysis}

Baseline (on depot OT) and follow-up (on pegvisomant) serum IGF-I, plasma glucose, NEFAs, total fat, \% fat and insulin sensitivity (both HOMA and sITT) were all normally distributed and compared using Student's

Table 1 Clinical characteristics of the seven patients.

\begin{tabular}{|c|c|c|c|c|c|c|c|}
\hline $\begin{array}{l}\text { Patient } \\
\text { no. }\end{array}$ & $\begin{array}{l}\text { Age } \\
\text { (years) }\end{array}$ & Gender & $\begin{array}{l}\text { Year of } \\
\text { diagnosis }\end{array}$ & $\begin{array}{l}\text { Surgery } \\
\text { (year) }\end{array}$ & $\begin{array}{l}\text { Radiotherapy } \\
\text { (dose (cGy), year) }\end{array}$ & $\begin{array}{l}\text { Replaced pituitary } \\
\text { hormone deficiencies }\end{array}$ & $\begin{array}{l}\text { Dose }(\mathrm{mg}) \text { and duration } \\
\text { (months) of OT therapy }\end{array}$ \\
\hline 1 & 46 & M & 1995 & 1995, 1996 & 4500,1995 & None & 20,19 \\
\hline 2 & 76 & $\mathrm{~F}$ & 1993 & - & - & None & 10,16 \\
\hline 3 & 55 & $\mathrm{~F}$ & 1994 & 1995 & 3750,1995 & ACTH, FSH/LH & 30,18 \\
\hline 4 & 58 & $M$ & 1981 & - & - & $\mathrm{FSH} / \mathrm{LH}$ & 30,18 \\
\hline 5 & 61 & M & 1981 & 1988 & 2000, 1988 & $\mathrm{FSH} / \mathrm{LH}$ & 30,19 \\
\hline 6 & 47 & $\mathrm{~F}$ & 1988 & 1988 & 4000,1988 & ACTH, TSH, FSH/LH & 30,18 \\
\hline 7 & 55 & $\mathrm{~F}$ & 1989 & 1990 & 4000, 1989 & ACTH, TSH & 10,17 \\
\hline
\end{tabular}


paired $t$-test, with statistical significance accepted at $P<0.05$. A regression analysis was used in order to assess whether the change in either fasting glucose concentration or IS could be predicted by the change in IGF-I between OT and pegvisomant therapies. All values are given as means \pm S.D.

\section{Results}

There was no statistically significant change in mean serum IGF-I concentrations between the beginning and conclusion of the study $(283 \pm 119 \mathrm{ng} / \mathrm{ml}$ on depot octreotide vs $191 \pm 39 \mathrm{ng} / \mathrm{ml}$ on pegvisomant, $P=0.4$; Fig. 1). Similarly, no change was observed either in total fat $(18551 \pm 4571 \mathrm{~g}$ vs $19562 \pm 4332 \mathrm{~g}$, $P=0.8)$ or in $\%$ fat $(25.3 \pm 8.1 \%$ vs $26.5 \pm 6.9 \%$, $P=0.34$ ) over the course of the study.

Fasting glucose concentrations were normal $(<6.0 \mathrm{mmol} / \mathrm{l})$ in all seven patients prior to commencement of OT (mean $4.6 \pm 0.6 \mathrm{mmol} / \mathrm{l}$ ). Mean fasting plasma glucose fell from $6.2 \pm 1.0 \mathrm{mmol} / \mathrm{l}$ on OT to $5.2 \pm 0.6 \mathrm{mmol} / \mathrm{l}$ on pegvisomant $(P=0.017)$ and was lower on pegvisomant in all seven patients (Fig. 2). In four patients, fasting plasma glucose concentrations fell from values diagnostic of either diabetes mellitus (DM) $(\geq 7.0 \mathrm{mmol} / \mathrm{l})$ or impaired fasting glucose $(6.0-6.9 \mathrm{mmol} / \mathrm{l})$ to normal on pegvisomant. Mean IS (by sITT) increased from 138.8 $\pm 38.8 \mu \mathrm{mol} / \mathrm{l}$ per $\mathrm{min}$ on OT to $169.0 \pm 55.8 \mu \mathrm{mol} / \mathrm{l}$ per $\mathrm{min}$ on pegvisomant $(P=0.037)$ and improved in six of the seven patients (Fig. 3). Mean IS (by HOMA \%S) was unchanged over the course of the study (155.3 $\pm 49.7 \%$ on OT vs $139.9 \pm 76.1 \%$ on pegvisomant, $P=0.28$; Fig. 4). Pancreatic $\beta$-cell secretory function (HOMA \%B) increased significantly on pegvisomant compared with OT $(49.4 \pm 19.2 \%$ vs $82.4 \pm 43.5 \%, \quad P=0.01$; Fig. 5). There was no statistically significant change in total NEFAs during the course of the study $(0.43 \pm 0.24$ vs $0.40 \pm 0.23$ $\mathrm{mmol} / \mathrm{l}, P=0.35)$.

\section{Discussion}

In this study, we have documented changes in IS in a group of patients initially treated with conventional, stable doses of a long-acting somatostatin analogue for a median of 18 months (range 16-19 months) and who were then transferred to therapy with the GHR antagonist pegvisomant for a median of 8 months (range 7-9 months). Recognizing the limitations imposed by the non-randomised design of the multi-centre protocol in which the patients were

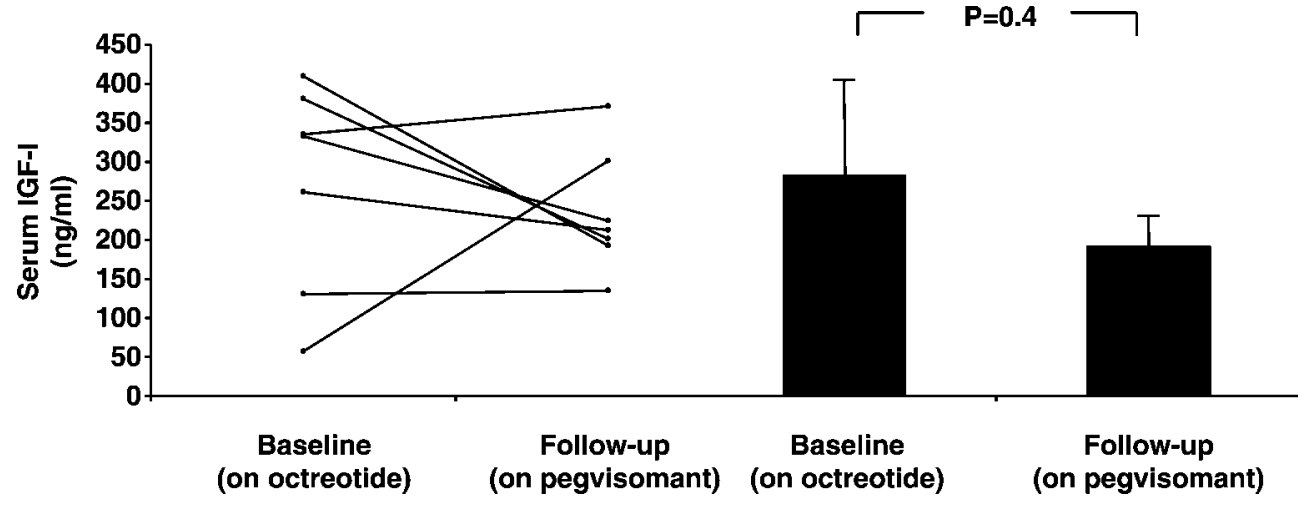

Figure 1 Serum IGF-I $(\mathrm{ng} / \mathrm{ml})$ in seven patients converted from OT to pegvisomant. Values are means \pm S.D.

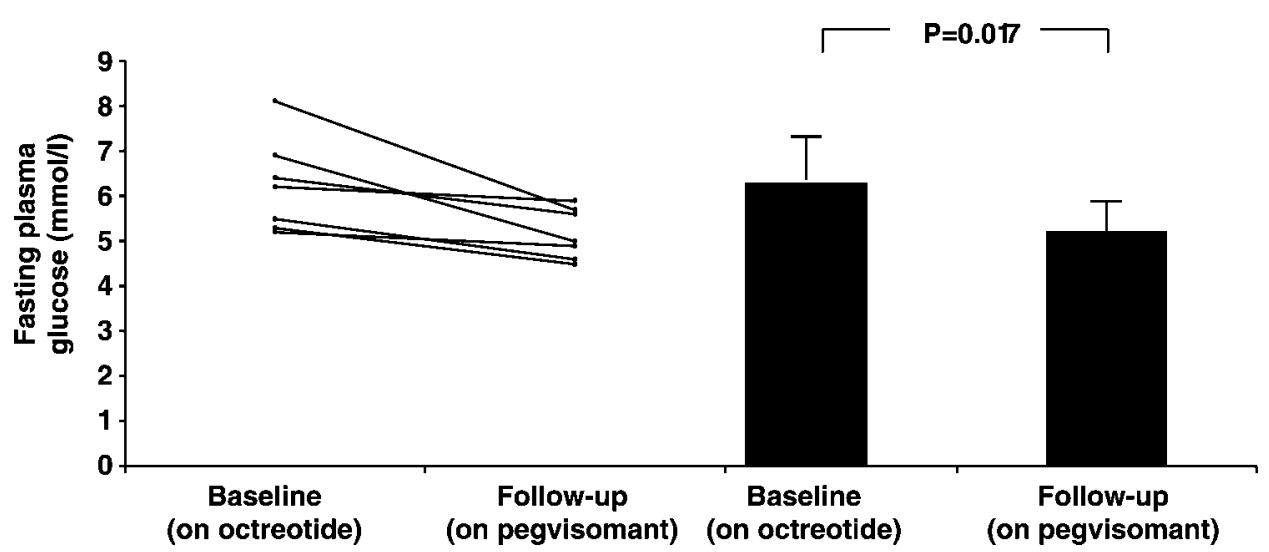

Figure 2 Plasma glucose concentrations $(\mathrm{mmol} / \mathrm{l})$ in seven patients converted from OT to pegvisomant. Values are means \pm S.D. 


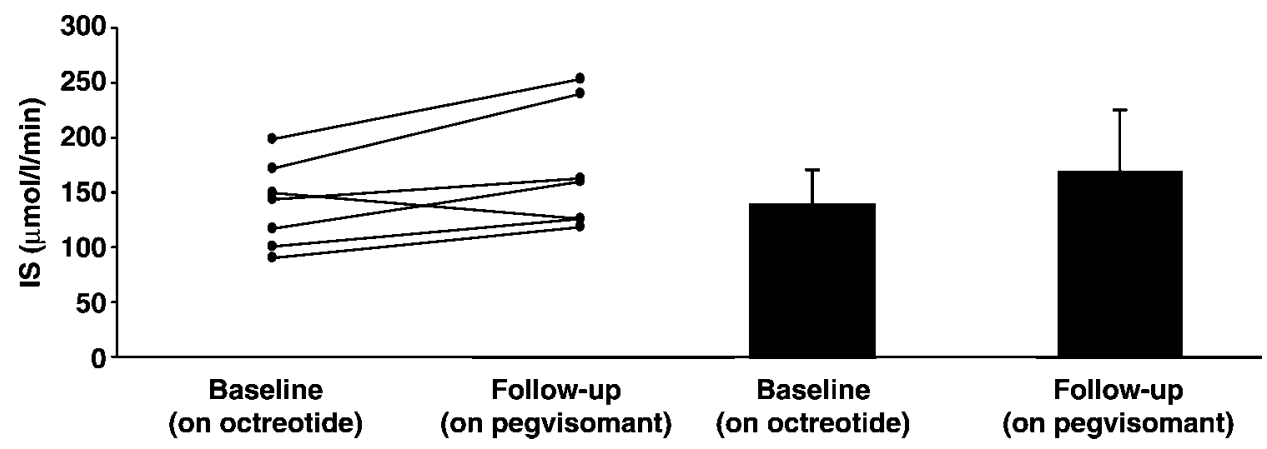

Figure 3 Peripheral IS ( $\mu \mathrm{mol} / / \mathrm{l}$ per $\mathrm{min}$ ) in seven patients converted from OT to pegvisomant. Values are means \pm S.D.

participating, the study has shown that fasting glucose concentrations were lower on pegvisomant in each of the seven patients, with levels falling to normal from values diagnostic of DM or impaired fasting glucose in four of the seven. There was a significant improvement in peripheral IS, as determined by sITT, but no change in 'whole body' IS, assessed by HOMA analysis. Pancreatic $\beta$-cell insulin secretory function $(\% \mathrm{~B})$ was significantly better on pegvisomant compared with octreotide. These changes in peripheral IS and carbohydrate tolerance occurred independently of changes in total or \% fat, as determined by DXA.

Much of the increased morbidity and mortality associated with acromegaly is accounted for by an increased risk of cardiovascular disease $(1,18,19)$. Although not definitely proven, it is thought that an important contributory factor to this increased prevalence of vascular disorders (notably hypertension, stroke and diastolic dysfunction leading to congestive cardiac failure) is the increased IR resulting from $\mathrm{GH}$ excess. Many of the actions of GH antagonise those of insulin (20): in normal individuals, administration of pharmacological doses of $\mathrm{GH}$ leads to hyperinsulinaemia $(21,22)$, worsens glucose tolerance (21) and reduces glucose uptake into peripheral tissues (22).
In the setting of clinical acromegaly, the diabetogenic effects of $\mathrm{GH}$ are clear, judged by the frequency with which impaired glucose tolerance (IGT) and type 2 DM develop in these patients $(23,24)$. These derangements of IS and glucose tolerance appear to be completely reversible when serum GH concentrations are reduced to 'safe' levels by surgical adenomectomy (25). However, the effect of somatostatin analogue therapy for acromegaly on glucose tolerance is complex and unpredictable $(13,14)$, owing to the action of this class of drug on endocrine cells other than adenomatous somatotrophs, such as the potent inhibition on insulin and glucagon secretion.

Although the precise mechanisms remain poorly understood, the IR of acromegaly is characterised by defects in the ability of insulin both to suppress hepatic glucose production and by impairment of glucose oxidation and uptake into peripheral tissues (26). Striated muscle is quantitatively the most important tissue for glucose disposal during hyperinsulinaemia (27) and, given that striated muscle is resistant to insulin action in the presence of GH excess (28), a decrease in glucose uptake is likely to be important in the pathogenesis of IGT in acromegaly. This study has clearly shown a significant improvement in peripheral IS in

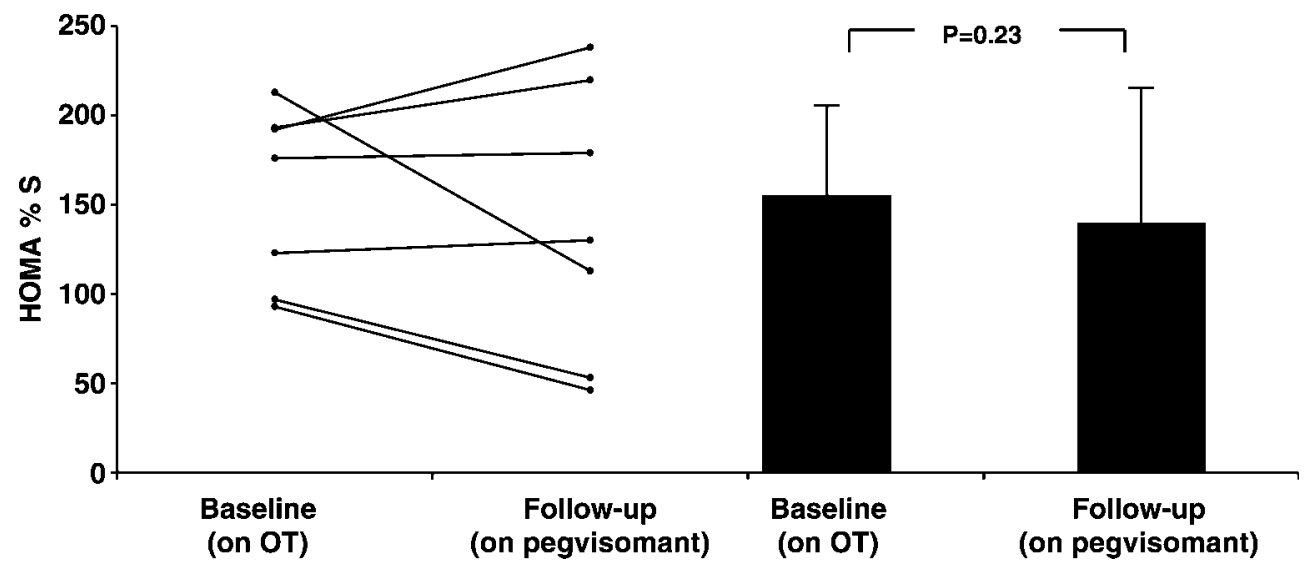

Figure 4 HOMA analysis of 'whole body' IS (\%S) in seven patients converted from OT to pegvisomant. Values are means \pm S.D. 


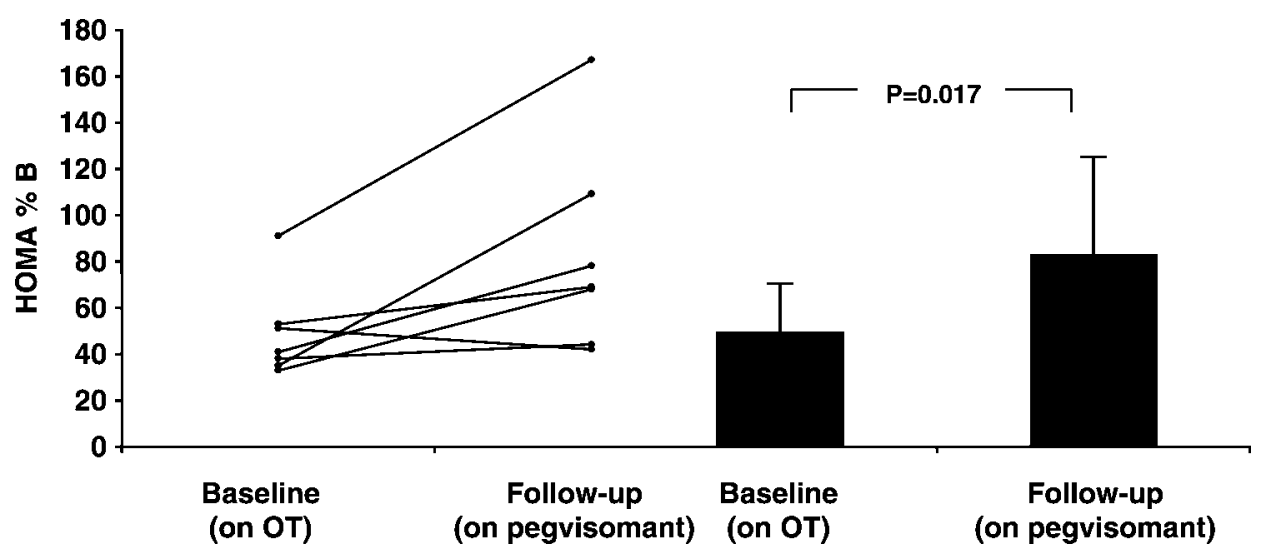

Figure 5 HOMA analysis of pancreatic $\beta$-cell secretory function (\%B) in seven patients converted from OT to pegvisomant. Values are means \pm S.D.

patients transferred from OT to pegvisomant, judged by the sITT, a technique that provides a robust measure of peripheral IS and which has been well validated against the 'gold standard' hyperinsulinaemic euglycaemic clamp (15). The mechanism for the improvement in peripheral IS is not clear. Peripheral IR in acromegaly is postulated to be due, at least in part, to the lipolytic action of $\mathrm{GH}$, with mobilisation of free fatty acids (FFAs) leading to 'Randle Cycle' substrate competition between glucose and lipid fuels in the periphery (29). The increase in glucose and FFA concentrations in turn leads to insulin secretion and a state of partially compensated hyperinsulinaemia. However, a reduction in lipolysis is unlikely to account for the improvement in peripheral IS demonstrated in this study, as there was no statistically significant change in circulating NEFAs between baseline (on OT) and follow-up (on pegvisomant). Further, although mean serum IGF-I fell during the course of the study, this was not statistically significant $(P=0.4)$ and there was no correlation between the change in serum IGF-I and change in peripheral IS. Beneficial effects on plasma glucose and insulin concentrations were documented in a recent observational study of long-term pegvisomant therapy in acromegaly (10). However, it is important to note that a substantial proportion of patients reported in that study were completely or partially OT resistant, such that the improvement in IS may simply have been consequent upon better biochemical control. The data presented in this study suggest that pegvisomant has a beneficial effect compared with OT on peripheral IS and glucose tolerance independent of the activity of the GH/IGF-I axis. In this context, it is interesting to note that mice expressing a GHR antagonist exhibit increased IS compared with controls and resistance to the development of glucose intolerance when injected with streptozotocin to induce diabetes, suggesting that activation of the GHR leads to altered IS with impairment of glucose utilisation $(30,31)$.

The improvement in peripheral IS demonstrated is not sufficient to explain the improvement in overall glucose tolerance, judged by the fall in fasting plasma glucose concentrations in all seven patients (Fig. 2). In acromegaly, the degree of IR per se does not predict glucose tolerance, as measurements of IS are equivalent in patients with or without carbohydrate intolerance (17). Compensatory $\beta$-cell hyperfunction is seen in those with normal glucose tolerance but not in patients with IGT or DM, indicating that it is $\beta$-cell reserve that determines the glucose tolerance state (17). This is supported by the observation that IS improves following surgical adenomectomy (25), whereas pancreatic $\beta$-cell reserve is unchanged (17). The fall in fasting plasma glucose concentrations in this study is likely to be due to an improvement in pancreatic $\beta$-cell function, suggested by the significant improvement in \%B. This, in turn, is likely to be due to withdrawal of the inhibitory effect of OT on insulin secretion, which is not influenced by pegvisomant. Somatostatin and its analogues decrease insulin release both in normal individuals $(32,33)$ and in patients with GH excess $(13,33,34)$. Further, a recent randomised study comparing the effects of OT and pegvisomant on the insulinogenic response to a standard meal documented inhibition of insulin release by OT with consequent postprandial hyperglycaemia (35). Insulin release and plasma glucose levels were not altered by administration of pegvisomant (35). Although the use of somatostatin analogues in acromegaly improves glucose tolerance in some patients by virtue of better control of the GH/IGF-I axis $(13,14)$, overall, OT therapy is associated with a significant deterioration in glucose tolerance (14). It seems likely, therefore, that increases in both peripheral IS and $\beta$-cell secretory function have contributed to the improved glucose tolerance observed in this cohort of patients transferred from therapy with OT to pegvisomant. The reason for the discrepancy between measurements of peripheral (sITT) and 'whole body' (HOMA \%S) IS is not clear, but suggests that disturbances of glucose disposal are of particular importance in the development of glucose intolerance in acromegaly. 
In summary, these preliminary data suggest that IS and glucose tolerance improve in patients transferred from stable somatostatin analogue therapy to treatment with pegvisomant. Clearly, larger randomized studies in de novo patients will be required to clarify this and, if confirmed, to establish the long-term implications of these changes. Endocrinologists can shortly look forward to a time when biochemical control (judged by a normal serum IGF-I concentration) is achievable for virtually all patients with acromegaly. In this context, factors such as convenience of administration, reduction in tumour volume (36) and the effects on IS reported here should all be carefully considered when deciding upon medical therapy for an individual patient.

\section{Acknowledgements}

The Department of Endocrinology at St Bartholomew's Hospital receives unrestricted support from Pharmacia for its research on $\mathrm{GH}$ and growth factors. We thank Mrs Enid Hennessy for her expert statistical assistance.

\section{References}

1 Bates AS, Van't Hoff W, Jones JM \& Clayton RN. An audit of outcome of treatment in acromegaly. Quarterly Journal of Medicine $199386293-299$.

2 Swearingen B, Barker FG, Katznelson L, Biller BM, Grinspoon S, Klibanski A et al. Long-term mortality after transsphenoidal surgery and adjunctive therapy for acromegaly. Journal of Clinical Endocrinology and Metabolism $1998 \mathbf{8 3} 3419-3426$.

3 Freda PU, Wardlaw SL \& Post KD. Long-term endocrinological follow-up evaluation in 115 patients who underwent transsphenoidal surgery for acromegaly. Journal of Neurosurgery $1998 \mathbf{8 9}$ 353-358.

4 Eastman RC, Gorden P \& Roth J. Conventional supervoltage irradiation is an effective treatment for acromegaly. Journal of Clinical Endocrinology and Metabolism 197948 931-940.

5 Biermasz NR, van Dulken H \& Roelfsema F. Long-term follow-up results of postoperative radiotherapy in 36 patients with acromegaly. Journal of Clinical Endocrinology and Metabolism 200085 2476-2482.

6 Abs R, Verhelst J, Maiter D, Van Acker K, Nobels F, Coolens JL et al. Cabergoline in the treatment of acromegaly: a study in 64 patients. Journal of Clinical Endocrinology and Metabolism 1998 83 374-378.

7 Vance ML \& Harris AG. Long-term treatment of 189 acromegalic patients with the somatostatin analogue octreotide. Results of the International Multicenter Acromegaly Study Group. Archives of Internal Medicine 1991151 1573-1578.

8 Flogstad AK, Halse J, Bakke S, Lancranjan I, Marbach P, Bruns C et al. Sandostatin LAR in acromegalic patients: long-term treatment. Journal of Clinical Endocrinology and Metabolism $1997 \mathbf{8 2}$ $23-28$.

9 Giusti M, Gussoni G, Cuttica CM \& Giordano G. Effectiveness and tolerability of slow release lanreotide treatment in active acromegaly: six-month report on an Italian multicenter study. Italian Multicenter Slow Release Lanreotide Study Group. Journal of Clinical Endocrinology and Metabolism 199681 2089-2097.

10 van der Lely A, Hutson R, Trainer P, Besser G, Barkan A, Katznelson L et al. Long-term treatment of acromegaly with pegvisomant, a growth hormone receptor antagonist. Lancet $20013581754-1759$.
11 Drake WM, Parkinson C, Besser GM \& Trainer PJ. Clinical use of a growth hormone receptor antagonist in the treatment of acromegaly. Trends in Endocrinology and Metabolism 200112 408-413.

12 Stewart PM. Pegvisomant: an advance in clinical efficacy in acromegaly. European Journal of Endocrinology $2003 \mathbf{1 4 8}$ $\mathrm{S} 27-\mathrm{S} 32$.

13 Ho KY, Jenkins D \& Furler SM. Impact of a long acting somatostatin analogue octreotide on glucose tolerance and insulin sensitivity in acromegaly. Clinical Endocrinology 199236 271-279.

14 Koop BL, Harris AG \& Ezzat S. Effect of octreotide on glucose tolerance in acromegaly. European Journal of Endocrinology 1994130 $581-586$.

15 Gelding SV, Robinson S, Lowe S, Nithtananthan R \& Johnston DG. Validation of the low dose short insulin tolerance test for evaluation of insulin sensitivity. Clinical Endocrinology $1994 \mathbf{4 0}$ 611-615.

16 Matthews DR, Hosker JP, Rudenski AS, Naylor BA, Treacher DF \& Turner RC. Homeostasis model assessment: insulin resistance and beta-cell function from fasting plasma glucose and insulin concentrations in man. Diabetologia 198528 412-419.

17 Kasayama S, Otsuki M, Takagi M, Saito H, Sumitani S, Kouhara H et al. Impaired beta-cell function in the presence of reduced insulin sensitivity determines glucose tolerance status in acromegalic patients. Clinical Endocrinology 200052 549-555.

18 Orme SM, McNally RJ, Cartwright RA \& Belchetz PE. Mortality and cancer incidence in acromegaly: a retrospective cohort study. United Kingdom Acromegaly Study Group. Journal of Clinical Endocrinology and Metabolism $1998 \mathbf{8 3} 2730-2734$.

19 Rajasoorya C, Holdaway IM, Wrightson P, Scott DJ, Ibbertson HK, Bates AS et al. Determinants of clinical outcome and survival in acromegaly. Clinical Endocrinology 1994 41 95-102.

20 Davidson MB. Effect of growth hormone on carbohydrate and lipid metabolism. Endocrine Reviews 19878 115-131.

21 Rosenfeld RG, Wilson DM, Dollar LA, Bennett A \& Hintz RL. Both human pituitary growth hormone and recombinant DNA-derived human growth hormone cause insulin resistance at a postreceptor site. Journal of Clinical Endocrinology and Metabolism $1982 \mathbf{5 4}$ 1033-1038.

22 Rizza RA, Mandarino LJ \& Gerich JE. Effects of growth hormone on insulin action in man. Mechanisms of insulin resistance, impaired suppression of glucose production, and impaired stimulation of glucose utilization. Diabetes 198231 663-669.

23 Sonksen PH, Greenwood FH, Ellis JP, Lowey C, Rutherford A \& Nabarro JDN. Changes of carbohydrate tolerance in acromegaly with the progress of the disease and its response to treatment. Journal of Clinical Endocrinology and Metabolism $1967 \quad 27$ $1418-1430$.

24 Wass JAH, Cudworth AG, Bottazzo GF, Woodrow JC \& Besser GM. An assessment of glucose intolerance in acromegaly and its response to medical treatment. Clinical Endocrinology 198012 53-59.

25 Moller N, Schmitz O \& Jorgensen JOL. Basal and insulin stimulated substrate metabolism in patients with active acromegaly before and after adenomectomy. Journal of Clinical Endocrinology and Metabolism $1992 \mathbf{7 4} 1012-1019$.

26 Hansen I, Tsalikian E, Beaufrere B, Gerich J, Haymond M \& Rizza R. Insulin resistance in acromegaly: defects in both hepatic and extrahepatic insulin action. American Journal of Physiology 1986 250 E269-E273.

27 DeFronzo RA, Jacot E, Jequier E, Maeder E, Wahren J \& Felber JP. The effect of insulin on the disposal of intravenous glucose. Results from indirect calorimetry and hepatic and femoral venous catheterization. Diabetes 198130 1000-1007.

28 Galbraith HJB, Ginsburg J \& Paton A. Decreased response to intra-arterial insulin in acromegaly. Diabetes $19609459-465$.

29 Randle PJ, Garland PB, Hales CN \& Newsholme EA. The glucose fatty acid cycle: its role in insulin sensitivity and the metabolic disturbance of diabetes mellitus. Lancet 1963 i 785-789.

30 Chen NY, Chen WY \& Kopchick JJ. A growth hormone antagonist protects mice against streptozotocin induced glomerulosclerosis 
even in the presence of elevated levels of glucose and glycated hemoglobin. Endocrinology 1996137 5163-5165.

31 Chen NY, Chen WY, Bellush L, Yang CW, Striker L, Striker GE et al. Effects of streptozotocin treatment in growth hormone $(\mathrm{GH})$ and GH antagonist transgenic mice. Endocrinology 19951362 660-667.

32 Mortimer CH, Carr D, Lind T, Bloom SR, Mallinson CN, Schally AV et al. Effects of growth hormone release-inhibiting hormone on circulating glucagon, insulin and growth hormone in normal, diabetic, acromegalic and hypopituitary patients. Lancet 1974 i $697-701$.

33 Davies RR, Miller M, Turner SJ, Goodship TH, Cook DB, Watson M et al. Effects of somatostatin analogue SMS 201-995 in normal man. Clinical Endocrinology 198624 665-674.

34 McKnight JA, McCance DR, Crothers JG \& Atkinson AB. Changes in glucose tolerance and development of gall stones during high dose treatment with octreotide for acromegaly. British Medical Journal $1989299604-605$
35 Parkinson C, Drake WM, Roberts ME, Meeran K, Besser GM \& Trainer PJ. A comparison of the effects of pegvisomant and octreotide on glucose, insulin, gastrin, cholecystokinin, and pancreatic polypeptide responses to oral glucose and a standard mixed meal. Journal of Clinical Endocrinology and Metabolism 200287 1797-1804.

36 Bevan JS, Atkin SL, Atkinson AB, Bouloux PM, Hanna F, Harris PE et al. Primary medical therapy for acromegaly: an open, prospective, multicenter study of the effects of subcutaneous and intramuscular slow-release octreotide on growth hormone, insulin-like growth factor-I, and tumor size. Journal of Clinical Endocrinology and Metabolism 200287 4554-4563.

Received 23 June 2003

Accepted 8 September 2003 